\title{
多入力線形システム理論に基づく観測記録を含む 時空間地震波形*
}

\section{川上英二** .小野牧夫***}

波形の変形を考慮した地中構造物に対する時空間関数としての入力波をシミュレート するための方法として，これまでに筆者らは，二重フーリエ級数を用いた方法，従来の 多変数の確率過程の理論を拡張する方法, AR モデルを用いた方法を展開している. 本 研究では, 従来の線形システム理論に基づき, 非観測地点での地震波形を, 観測記録を 入力とする多入力線形システムの出力として周波数領域で取り扱う方法を展開し，その 適用例を示すことを目的としている。

Key Words : earthquake, ground motion, simulation, underground structures

\section{1. 序文}

トンネル，パイプライン，地中埋設管路等の地震波動 の伝播に伴う動的応答解析, 耐震設計を行う場合, まず, 管路・地盤・基盤を力学的にモデル化し, 地盤または基 盤における地震動を入力する必要がある ${ }^{11}$.地盤または 基盤からの地震入力は, 管路に沿った各点で与える必要 があり，この各点での変位の時刻歴を，つまり，時間及 び空間の関数としての地震波形をどのように想定するか は，管路の応答に支配的な影響を及ぼすため重要な問題 である。

従来, 時間に関する入力地震動としては, Imperial Valley 地震, T aft 地震, 十勝沖地震, 新潟地震等の過 去の地震においてある一地点で実測された強震観測記録 に基づく波形が用いられる事が多い。 また，得られた波 形を場所に関して一定の速度で伝播させてきた.

しかし，地震波の水平方向のみかけ伝播速度として， 石油パイプライン基準 ${ }^{21}$ のうに地盤のせん断波速度を 用いるか，アレー観測記録の相互相関関数のピークから 求められた值 ${ }^{31}$ (5) を用いる ${ }^{6)}$ かでは結果が著しく異なる 可能性がある．合理的であるという点では，みかけ速度 としては後者の值を用いるのが妥当であるが, この場合, 波形が場所によらず同一であると仮定し，波形の変形の 影響を無視しているため, 危険な設計を行う可能性があ るという問題がある7゙.

一方，観測波形を変形させずにそのまま伝播させて用 いる上述の方法に代わる方法として, 時間・空間の関数 としての地震動のシミュレーションに関する研究が, こ

* 本論文の一部は, 土木学会第 47 回年次学術講演会 (1992.9), 参考文献 21）に発表したものである.

**正会員 工博 埼玉大学教授 工学部建設工学科 ( (338 浦和市下大久保 255)

****正会員 東京ガス(株) 元埼玉大学大学院 理工学研究科 学生
れまでに幾つか行われてきた81〜16!. しかしながら，これ らのシミュレーションでは，何れの方法においても，観 測された強震記録をよ゙の地点においても正確には満足し ていないために，耐震設計に際しては，より現実的な地 震波形であるという理由から，実際に観測された強震波 形を簡単に伝播させて応答計算を行ってしまう場合が多 いものと考えられる.

以上のような観点 (参考文献 17 の 1. 序論に詳述) から，地中線状構造物に対する地震動の時間のみでなく 場所に関する変動, つまり, 波動の伝播及び波形の変形, を考慮した代表的な，かつ，現実的な地震波形を作るた めの手法の研究が必要であると考える.

著者らは，これまでに，二重フーリ工級数を用いる手 法 $^{181,191}$, 従来の多変数の確率過程を拡張する方法 ${ }^{17}$, AR モデルを用いる方法201を既に展開している. そして, 観測記録を含む時空間地震波形をシミュレートする一つ の適用例として, Imperial Valley 地震の観測記録を含 む時空間関数としての地震波形を求めている.

本論文で展開する手法は, 従来の線形システム理論に 基づくものであり, 非観測地点の地震波形を，観測記録 を入力とする線形システムの出力として取り扱うもので ある. そして, 時間について定常な場において複数の観 測記録が与えられている場合を想定し，これら観測記録 を含む時空間関数としての地震波形をシミュレートする ための手法の開発を目的としている.

まず, 地盤の変位を互いに相関を有する複数の確率過 程と考える.この時空間確率過程は，これまでの研 究 ${ }^{171211}$ と同様に次の 2 つ条件を満足するものと仮定 する.

条件 (A)：時空間確率過程と観測波形との時間に関 する自己相関関数（またはパワースペクトル）は一致す る. 観測波形の自己相関関数と, 従来の研究に基づく, 地震波のみかけの伝播速度, 波形の変形の程度（コヒ一 
レンシー）とから，相互相関関数（またはクロススペク トル）を想定する. 時空間確率過程の相互相関関数は, 想定した相互相関関数に一致する.

条件 $(B)$ ：時空間確率過程は, 多地点の観測地点に おいては観測波形に厳密に一致する.

本論文では，条件（A）で与える相互相関関数を，波 が正方向にある一定の速度で伝播し，また，二地点間距 離が離れる程, 相関が減少するような関数とした. さら に, 適用例として, Imperial Valley 地震によるE1 Centro 地震波形を観測波形として，いくつかのシミュ レーションを行った.

なお，主に都市のサイズミック・モニタリングの立場 から，既知波形を条件とする時空間地震波形のシミュ レーション手法が, 最近幾つか提案されている. フーリ 工係数に関する条件付確率密度関数に基づく方法が盛 川・亀田 ${ }^{221,23)}$ により, また Kriging 手法に基づく方法が, Vanmarcke $\cdot$ Fenton $^{24)}$, 星谷 ${ }^{25)}$, 丸山・星谷 ${ }^{26)}$, 土岐・ 佐藤・清野・水谷 ${ }^{27)}$ によって提案されている.

これまでに提案されてきた方法を，条件付時空間波形 のシミュレーション理論として総括すると, 大きく次の ように分類できる.

（1）各々の時空間サンプルが，条件（A）を満足す る方法

(1) 二重フーリエ級数を用いる方法 ${ }^{18,19)}$

（2）多くの時空間サンプルのアンサンブル平均が, 条件 (A) を満足する方法

(a) 振動数領域での方法

(2) 不規則確率過程のシミュレーション理論 に基づく方法 ${ }^{171}$

(3) 多入力線形システム理論に基づく方法211

(4) Kriging 手法に基づく方法 ${ }^{241}$

(5)フーリ工係数に関する条件付確率密度関 数を扱う方法 ${ }^{221,231}$

（b）時間領域での方法

(6) 多変数 (両側) AR モデルを用いる方法 ${ }^{201}$

(7) Kriging 手法に基づく方法 ${ }^{261,27)}$

本論文で提案している方法は，(3)であるため，(2)（5) の方法の違いを以下に示す.

まず，(4)で用いられている Kriging 手法は, 内挿方法 として発展したものである. このため, 非観測地点の值 を, 観測地点の值の線形和として表し, その係数は実数 である.Vanmarcke $ら^{24}$ も sin 関数, cos 関数の係数 (実 数であることに注意) をそれぞれ別々に考え，これらの 係数の場所に関する内挿を行っている. 非観測地点の $\sin$ 関数の係数を, 観測地点の $\sin$ 関数の係数の線形和 として, また, 非観測地点の $\cos$ 関数の係数を, 観測地 点の $\cos$ 関数の係数の線形和として扱っている. また, (5)の方法は, その際に, 係数の分布をも考慮したもので
ある。

一方, 提案した(3)の方法では,「内挿」の概念ではなく， 「応答」の考えを用いている. 非観測地点の波形を観測 地点の波形が入力した際の線形応答として考えている. 線形関数を用いる点では Kriging 法と共通しているが, 式の見かけ上も異なり,係数は実数でなく複素数である. これらが，(3)の方法の大きな特徵である. 本方法は, Kriging 手法を複素数の領域に拡張したものとみなすこ とも可能かもしれない. しかし，複素数で扱うことは, 実数を扱う Kriging 法を単に 2 回繰り返すことに一致し ない. 実数に書き直しても，例えば， sin 関数の係数が, $\sin$ 関数の係数だけでなく, $\cos$ 関数の係数とも関係し ていることになり，結果は異なっている.

以上の理由により, 本方法(3)は, Kriging 法を拡張し た方法であるとはみなしていない. Kriging 手法よりも 歴史の古い線形システムの応答理論を適用した方法であ るとみなす方が素直であると考えている.

一方，従来の不規則過程のシミュレーションによく使 われる定式化に基づく方法が，著者らが既に提案した方 法(2)である. 本方法は, 方法(3)の入力として，観測波形 の代わりにホワイトノイズを用いた場合であるとみなす ことも可能である.

\section{2. 時空間確率過程のクロススペクトル}

場所 $i$ と時間 $t$ における地盤の変位を, 互いに相関を 有する確率過程 $u_{i}(t)(i=1,2, \cdots, I)$ で表す. $u_{i}(t)$ は, 次式のようにフーリエ級数に展開できる.

$$
u_{i}(t)=\sum_{n=-N}^{N} U_{i}\left(\omega_{n}\right) \exp \left(i \omega_{n} t\right)
$$

ここで， $\omega_{n}$ は円振動数であり，記録長 $T$ を用いて次式 で表される.

$$
\omega_{n}=n \cdot \Delta \omega=\frac{2 n \pi}{T} \quad(n=-N, \cdots, N) \cdot
$$

なお，ここでは, 時間 0〜Tの範囲での定常性を仮定し ている.

式 (1)の $U_{i}\left(\omega_{n}\right)$ は複素フーリ工係数であり, 次式 で求めることができる.

$$
U_{i}\left(\omega_{n}\right)=(1 / T) \int_{0}^{T} u_{i}(t) \exp \left(-i \omega_{n} t\right) d t
$$

ただし，

$$
U_{i}\left(\omega_{(-n)}\right)=U_{i}^{*}\left(\omega_{n}\right)
$$

である.ここで，＊は共役複素数を表す.

式（1）のように, 確率過程をフーリ工級数に展開す ると, 時空間地震波形の両側パワースペクトルは,

$$
S_{i i}\left(\omega_{n}\right) \Delta \omega=E\left[\left|U_{i}\left(\omega_{n}\right)\right|^{2}\right] \cdot
$$

となる.ここで， $E[$ ］ はアンサンブル平均を表す. また，クロススペクトルは次式で求めることができる。

$S_{i j}\left(\omega_{n}\right) \Delta \omega=E\left[U_{i}^{*}\left(\omega_{n}\right) U_{j}\left(\omega_{n}\right)\right]$ ( 6 ) 


\section{3. シミュレーションの理論}

今, 地点 $x_{i}(i=1,2, \cdots, I)$ を対象亡し, その中の地 点 $x_{k}(k=1,2, \cdots, K)$ (観測地点) において 観測記録 $u_{k}(t)$ がサンプルとして得られているとする.このとき, 非観 測地点 $x_{v}(v=K+1, K+2, \cdots, I)$ の内の先ずは一地点 $x_{v}$ だけを考え, この地点における地震波形 $u_{v}(t)$ を次式で 表す.

$$
u_{v}(t)=\sum_{k=1}^{K} \sum_{n=-N}^{N} H_{k}\left(\omega_{n}\right) U_{k}\left(\omega_{n}\right) \exp \left(i \omega_{n} t\right)+z(t)
$$

ただし， $U_{k}\left(\omega_{n}\right)$ は観測記録の複素フーリ工係数であ り, $H_{k}\left(\omega_{n}\right)$ は未知の複素係数である.

ここで, 上式の物理的な意味を考える亡, $u_{v}(t)$ を, 観測記録 $u_{k}(t)(k=1, \cdots, K)$ を入力とする線形システム の出力波形とすれば, $H_{k}\left(\omega_{n}\right)$ は振動数応答関数と考え ることができる. また， $z(t)$ は付加雑音である. 従来 の線形システムの理論と同様に, 出力波形には, 雑音波 形が加わっている場合を考えている.

さて,上式を用いて非観測地点における地震波形 $u_{v}(t)$ をシミュレートするためには, 複素係数 $H_{k}\left(\omega_{n}\right)$ 亡付 加雑音 $z(t)$ を求める必要がある.

まず，複素係数 $H_{k}\left(\omega_{n}\right)$ を求める. 上式で $u_{v}(t)$ と $z$ $(t)$ をそれぞれフーリエ級数に展開すると次式を得る.

$$
\begin{aligned}
U_{v}\left(\omega_{n}\right)= & \sum_{k=1}^{K} H_{k}\left(\omega_{n}\right) U_{k}\left(\omega_{n}\right)+Z\left(\omega_{n}\right) \\
& (n=-N, \cdots, N) \cdots \cdots \cdots \cdots \cdots \cdots \cdots \cdots
\end{aligned}
$$

ただし, $U_{v}\left(\omega_{n}\right)$ は非観測地点における地震波形 $u_{v}(t)$ の複素フーリ工係数, $Z\left(\omega_{n}\right)$ は付加雑音 $z(t)$ の複素フー リエ係数である。

式（8）の両辺に $U_{c}^{*}\left(\omega_{n}\right)(c=1, \cdots, K)$ を乗じてア ンサンブル平均をとると,

$$
\begin{aligned}
E\left[U_{c}^{*}\left(\omega_{n}\right) U_{v}\left(\omega_{n}\right)\right]= & \sum_{k=1}^{K} H_{k}\left(\omega_{n}\right) E\left[U_{c}^{*}\left(\omega_{n}\right) U_{k}\left(\omega_{n}\right)\right] \\
& +E\left[U_{c}^{*}\left(\omega_{n}\right) Z\left(\omega_{n}\right)\right] \cdots(9)
\end{aligned}
$$

となる.ここで, 付加雑音 $z(t)$ は観測記録 $u_{c}(t)(c=1$, $\cdots, K)$ 亡無相関であると仮定すると，上式は，

$$
S_{c v}\left(\omega_{n}\right) \Delta \omega=\sum_{k=1}^{K} H_{k}\left(\omega_{n}\right) S_{c k}\left(\omega_{n}\right) \Delta \omega \cdots
$$

となる。

上式をマトリックス表示すると次の連立一次方程式と なる。

$$
\left[\begin{array}{c}
S_{1 v}\left(\omega_{n}\right) \Delta \omega \\
\vdots \\
S_{K v}\left(\omega_{n}\right) \Delta \omega
\end{array}\right]=\left[\begin{array}{ccc}
S_{11}\left(\omega_{n}\right) \Delta \omega & \cdots & S_{1 K}\left(\omega_{n}\right) \Delta \omega \\
\vdots & \ddots & \vdots \\
S_{K 1}\left(\omega_{n}\right) \Delta \omega & \cdots & S_{K K}\left(\omega_{n}\right) \Delta \omega
\end{array}\right]
$$

$$
\cdot\left[\begin{array}{c}
H_{1}\left(\omega_{n}\right) \\
\vdots \\
H_{K}\left(\omega_{n}\right)
\end{array}\right]
$$

この式より複素係数 $H_{k}\left(\omega_{n}\right)(k=1, \cdots, K)$ の不偏推定值 を求めることができる.

次に, 付加雑音 $z(t)$ をシミュレートする. 式（8) の両辺に $U_{v}^{*}\left(\omega_{n}\right)$ をかけてアンサンブル平均をとると,

$$
\begin{aligned}
E\left[U_{v}^{*}\left(\omega_{n}\right) U_{v}\left(\omega_{n}\right)\right]= & \sum_{k=1}^{K} H_{k}\left(\omega_{n}\right) E\left[U_{v}^{*}\left(\omega_{n}\right) U_{k}\left(\omega_{n}\right)\right] \\
& +E\left[U_{v}^{*}\left(\omega_{n}\right) Z\left(\omega_{n}\right)\right] \cdots \cdots(12)
\end{aligned}
$$

となる. 式（8）（12）と, 観測記録と付加雑音との無 相関性

$$
E\left[U_{k}^{*}\left(\omega_{n}\right) Z\left(\omega_{n}\right)\right]=0 \quad(k=1, \cdots, K)
$$

より, 付加雑音 $z(t)$ のパワースペクトル $S_{z z}\left(\omega_{n}\right) \Delta \omega$ は 次式となる.

$$
\begin{aligned}
S_{z z}\left(\omega_{n}\right) & \Delta \omega=S_{v v}\left(\omega_{n}\right) \Delta \omega \\
& -\sum_{k=1}^{K} H_{k}\left(\omega_{n}\right) S_{v k}\left(\omega_{n}\right) \Delta \omega
\end{aligned}
$$

上式のパワースペクトル $S_{z z}\left(\omega_{n}\right) \Delta \omega$ を持つ付加雑音 $z(t)$ は，次式により作成することができる ${ }^{281,29 !}$.

$$
z(t)=\sum_{n=-N}^{N} \sqrt{S_{z z}\left(\omega_{n}\right) \Delta \omega} \cdot \exp \left\{i\left(\omega_{n} t+\phi_{n}\right)\right\}
$$

ここで，位相角 $\phi_{n}$ は，0〜2 $\pi$ の範囲で互いに独立な 一様乱数とする.ただし，

$$
\phi_{(-n)}=-\phi_{n}
$$

である。

以上により，多地点での観測記録から非観測地点の地 震波形を作成することができる.しかし，これだけでは， 非観測地点の波形間の相関性が考慮されていない, 以下 では, 非観測地点の波形間の相関性をも考慮できるシ ミュレーション手法として 2 つの方法を示す.

\section{a) 方法 1}

非観測地点 $x_{v}(v=K+1, K+2, \cdots, I)$ の地震波形 $u_{v}(t)$ を，それぞれ観測記録 $u_{k}(t)(k=1,2, \cdots, K)$ からシミュ レートするため, 式 $(7)$ と同様にして,

$$
u_{v}(t)=\sum_{k=1}^{K} \sum_{n=-N}^{N} H_{v k}\left(\omega_{n}\right) U_{k}\left(\omega_{n}\right) \exp \left(i \omega_{n} t\right)+z_{v}(t)
$$

とおく.ここで, 複素係数 $H_{v k}\left(\omega_{n}\right)(k=1,2, \cdots, K)$ の 不偏推定值は, 式 (11) 亡同様に, 次の連立一次方程 式で求めることができる.

$$
\begin{aligned}
{\left[\begin{array}{c}
S_{1 v}\left(\omega_{n}\right) \Delta \omega \\
\vdots \\
S_{K v}\left(\omega_{n}\right) \Delta \omega
\end{array}\right]=} & {\left[\begin{array}{ccc}
S_{11}\left(\omega_{n}\right) \Delta \omega & \cdots & S_{1 K}\left(\omega_{n}\right) \Delta \omega \\
\vdots & \ddots & \vdots \\
S_{K 1}\left(\omega_{n}\right) \Delta \omega & \cdots & S_{K K}\left(\omega_{n}\right) \Delta \omega
\end{array}\right] } \\
& \cdot\left[\begin{array}{c}
H_{v 1}\left(\omega_{n}\right) \\
\vdots \\
H_{v K}\left(\omega_{n}\right)
\end{array}\right] \cdots \cdots \cdots \cdots \cdots \cdots \cdots(18)
\end{aligned}
$$

式 (18) を $v=K+1, K+2, \cdots, I$ について解くことに より, 複素係数 $H_{v k}\left(\omega_{n}\right)$ を決定することできる. また, 式 (14) と同様にして, 付加雑音 $z_{v}(t)(v=K+1, K+$ $2, \cdots, I)$ は次式のようなクロススペクトルを持つことが 
わかる。

$$
\begin{aligned}
& S_{z, p q}\left(\omega_{n}\right) \Delta \omega=E\left[Z_{p}^{*}\left(\omega_{n}\right) Z_{q}\left(\omega_{n}\right)\right] \\
& \quad=S_{p q}\left(\omega_{n}\right) \Delta \omega-\sum_{k=1}^{K} H_{q k}\left(\omega_{n}\right) S_{p k}\left(\omega_{n}\right) \Delta \omega \\
& \quad(p, q=K+1, K+2, \cdots, I) \cdots \cdots \cdots \cdots \cdots \cdots \cdots \cdots \cdots \cdots \cdots \cdots \cdots \cdots . \cdots
\end{aligned}
$$

よって, 式（19）で求まるクロススペクトルを有す る付加雑音 $z_{v}(t)$ をシミュレートすればよいことになる. 従来のシミュレーション手法年, 299を用いると, 付加雑音 $z_{v}(t)$ は次式によりシミュレートすることができる.

$$
z_{v}(t)=\sum_{m=K+1}^{v} \sum_{n=-N}^{N} F_{v m}\left(\omega_{n}\right) \sqrt{\Delta \omega} \cdot \exp \left\{i\left(\omega_{n} t+\phi_{m n}\right)\right\}
$$

ここで, 式 $(20)$ の $F_{v m}\left(\omega_{n}\right) \sqrt{\Delta \omega}$ は, 付加雑音のス ペクトルマトリックスを次のように分解して求めること ができる.

$$
\begin{aligned}
& {\left[\begin{array}{ccc}
S_{z,(K+1)(K+1)}\left(\omega_{n}\right) \Delta \omega & \cdots & S_{z,(K+1) I}\left(\omega_{n}\right) \Delta \omega \\
\vdots & \ddots & \vdots \\
S_{z, I(K+1)}\left(\omega_{n}\right) \Delta \omega & \cdots & S_{z, I I}\left(\omega_{n}\right) \Delta \omega
\end{array}\right]} \\
& =\left[\begin{array}{ccc}
F_{(K+1)(K+1)} *\left(\omega_{n}\right) \sqrt{\Delta \omega} & & 0 \\
\vdots & \ddots & \\
F_{I(K+1)} *\left(\omega_{n}\right) \sqrt{\Delta \omega} & \cdots & F_{I I} *\left(\omega_{n}\right) \sqrt{\Delta \omega}
\end{array}\right] \\
& \cdot\left[\begin{array}{ccc}
F_{(K+1)(K+1)}\left(\omega_{n}\right) \sqrt{\Delta \omega} & \cdots & F_{I(K+1)}\left(\omega_{n}\right) \sqrt{\Delta \omega} \\
& \ddots & \vdots \\
0 & & F_{I I}\left(\omega_{n}\right) \sqrt{\Delta \omega}
\end{array}\right]
\end{aligned}
$$

ただし，

$$
F_{v m}\left(\omega_{-n}\right) \sqrt{\Delta \omega}=F_{v m}^{*}\left(\omega_{n}\right) \sqrt{\Delta \omega}
$$

である。また，位相角 $\phi_{m n}$ は，0 $2 \pi$ の範囲で互いに 独立な一様乱数とする. ただし，

$$
\phi_{m(-n)}=-\phi_{m n}
$$

である.

このように, 非観測地点における地震波形は, 観測記 録 $u_{k}(t)$ と，互いに相関を有する付加雑音 $z_{v}(t)$ とから シミュレートすることができる.

b) 方法 2

観測記録 $u_{k}(t)(k=1, \cdots, K)$ 加 , 非観測地点 $x_{v}(v=$ $K+1, \cdots, I)$ の中の一地点 $x_{K+1}$ の地震波形 $u_{K+1}(t)$ をシ ミュレートすると, 式 $(7)$ と同様にして,

$$
\begin{aligned}
& u_{K+1}(t)=\sum_{k=1}^{K} \sum_{n=-N}^{N} H_{(K+1) k}\left(\omega_{n}\right) U_{k}\left(\omega_{n}\right) \exp \left(i \omega_{n} t\right) \\
& +z_{K+1}(t) \text {. }
\end{aligned}
$$

となる.ここで, 複素係数 $H_{(K+1) k}$ は, 式 (11) と同様に, 次式により求めることができる.

$$
\left[\begin{array}{c}
S_{1(K+1)}\left(\omega_{n}\right) \Delta \omega \\
\vdots \\
S_{K(K+1)}\left(\omega_{n}\right) \Delta \omega
\end{array}\right]=\left[\begin{array}{ccc}
S_{11}\left(\omega_{n}\right) \Delta \omega & \cdots & S_{1 K}\left(\omega_{n}\right) \Delta \omega \\
\vdots & \ddots & \vdots \\
S_{K 1}\left(\omega_{n}\right) \Delta \omega & \cdots & S_{K K}\left(\omega_{n}\right) \Delta \omega
\end{array}\right]
$$

$$
\left[\begin{array}{c}
H_{(K+1) 1}\left(\omega_{n}\right) \\
\vdots \\
H_{(K+1) K}\left(\omega_{n}\right)
\end{array}\right]
$$

また, 付加雑音 $z_{K+1}(t)$ のパワースペクトルは, 式 (14) 之同様に，

$$
\begin{array}{r}
S_{z,(K+1)(K+1)}\left(\omega_{n}\right) \Delta \omega=S_{(K+1)(K+1)}\left(\omega_{n}\right) \Delta \omega \\
\quad-\sum_{k=1}^{K} H_{(K+1) k}\left(\omega_{n}\right) S_{(K+1) k}\left(\omega_{n}\right) \Delta \omega \cdots
\end{array}
$$

となるので, 付加雑音 $z_{K+1}(t)$ は式（15） と同様に次式 でシミュレートできる.

$$
\begin{aligned}
z_{K+1}(t)= & \sum_{n=-N}^{N} \sqrt{S_{z,(K+1)(K+1)}\left(\omega_{n}\right) \Delta \omega} \\
& \cdot \exp \left[i\left\{\omega_{n} t+\phi_{(K+1) n}\right\}\right] \cdots
\end{aligned}
$$

次に, 地点 $x_{K+2}$ の地震波形 $u_{K+2}(t)$ をシミュレート するときは，シミュレートした $u_{K+1}(t)$ を観測記録に加 えて, 式 (24) から (27) の $K$ を $K+1$ と置き換えて 同様にしてシミュレートする. 以下同様に, シミュレー トした波形を順次，観測記録に加えて行くことにより， 複数の非観測地点における地震波形をシミュレートする ことができる.

方法 1 のように一括して求める方法は, 参考文献 17) でも用いているように従来からの方法である．また，方 法 2 の上うに漸次的に波形を求める方法は, 参考文献 21) で周波数領域において既に提案したものである. 尚, 星谷 ${ }^{25}$ は時間領域において同様な方法を提案している.

\section{4. 時空間地震波形のクロススペクトルの想定}

本論文では，変形しながら伝播する波動を，1.の条件 （A）より, 各地点での波動の振動数パワースペクトル は，観測記録のパワースペクトルから想定されるものと し, 二地点 $i, j$ での波動のクロススペクトル $S_{i j}(\omega)$ に おいて相関の程度が減少しながら伝播する波動亡考えて いる.

実際の地震波においても, 離れた二地点で観測された 波形を比較すると, 二地点間の距離 $\left|x_{i j}\right|$ が大きいほど, また長周期の波より短周期の波ほざ二地点での波形は異 なり相関が小さくなる傾向があるもの考えられる301-32!.

そこで, 変形しながら伝播する波動のクロススペクト ル $S_{i j}(\omega)$ を振動数 $|\omega|$ と伝播時間 $\left|x_{i j}\right| / c, \quad(c$ : 地震波 の地表面に沿うみかけの伝播速度) の関数である $A(|\omega|$ $\left.\left|x_{i j}\right| / c\right)$ を用いて次式のように表せるものと仮定した.

$$
\begin{aligned}
& S_{i j}(\omega)=\sqrt{S_{i i}(\omega)} \sqrt{S_{j j}(\omega)} A\left(|\omega|\left|x_{i j}\right| / c\right) \\
& \cdot \exp \left(-i \omega x_{i j} / c\right)
\end{aligned}
$$

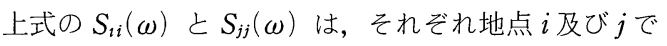
の地震波動の両側パワースペクトルである. また, 関数 $A(）$ はコヒーレンシーとよばれているものであり, 石井の研究 ${ }^{301}$ に基づき, 
$A\left(|\omega|\left|x_{i j}\right| / c\right)=\exp \left\{-\alpha|\omega| \| x_{i j} \mid /(2 \pi c)\right\}$

と仮定した。ここで， $\alpha$ は波形の変形しやすさの程度を 表すパラメーターであり，これを変形定数と呼んでい $3^{7), 17)-19)}, \alpha=0$ は波形が変形しない場合を表しており, $\alpha$ が大きい程, 二地点の波形の相関は減少する.

式（28）の両辺に $\Delta \omega$ を乗ずることにより，線クロス スペクトルに対する表記は次式となる.

$$
\begin{aligned}
& S_{i j}(\omega) \Delta \omega=\sqrt{S_{i i}(\omega) \Delta \omega} \sqrt{S_{j j}(\omega) \Delta \omega} \\
& \cdot \exp \left\{-\alpha|\omega| \mid x_{i j} / /(2 \pi c)\right\} \cdot \exp \left(-i \omega x_{i j} / c\right)
\end{aligned}
$$

ちなみに，想定する相互相関関数 $R_{X T}^{0}\left(x_{i j}, \tau\right)$ はクロ ススペクトルを逆フーリエ変換して,

$$
\begin{aligned}
& R_{X T}^{0}\left(x_{i j}, \tau\right)=\int_{-\infty}^{\infty} S_{i j}(\omega) \exp (i \omega \tau) d \omega \\
& \quad=\sum_{n=-N}^{N} \sqrt{S_{i i}\left(\omega_{n}\right) \Delta \omega} \sqrt{S_{j j}\left(\omega_{n}\right) \Delta \omega} \\
& \quad \cdot \exp \left\{-\alpha\left|\omega_{n}\right|\left|x_{i j}\right| /(2 \pi c)\right\} \cdot \exp \left\{i \omega_{n}\left(\tau-x_{i j} / c\right)\right\}
\end{aligned}
$$

で，求める事ができる.

上述の想定で用いられるパラメーターであるみかけの 伝播速度 $c$ と変形定数 $\alpha$ については, アレ一観測結果 を基に幾つかの值が算定されている．これらの值は，地 盤条件，伝播経路の条件，断層の条件などによって異な る可能性があることが予想されるが，現在のところどう 変わるかは全くわかっていない. 観測および解析の結果 を待つより仕方がない. ただ少数の解析結果から判って いることは,

(1) みかけの伝播速度は数 $\mathrm{km} / \mathrm{s}$ であり, 地盤の $S$ 波 速度より 1 桁も大きい.

(2) 波形は変形する.

であり，これらの知見を全く無視した設計には問題があ るということである．值はばらつくものとして考える必 要がある.

相互相関関数の想定に際しても，1つのアレーでの 1 つの地震による観測波形からの想定, 1 アレーでの多地 震からの想定, 類似した地盤条件の多アレーでの多地震 からの想定などが考えられる. シミュレーション結果の 使用目的によって異なるものと考えられる.

\section{5. 計算手順のまとめ}

本論文で提案した多地点の観測記録を含む時空間地震 波形のシミュレーションの方法は, 以下の手順にまとめ られる.

(1) 観測波形を式（1）のようにフーリエ級数に展開 し, 複素フーリ工係数を求める.

(2) 確率過程の番号 $i$ 之場所 $x_{i}$ 之の関係を設定する.

(3) 非観測地点での波動のパワースペクトルを，観測

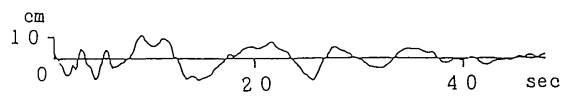

図一1 Imperial Valley 地震（1940）の観測波形

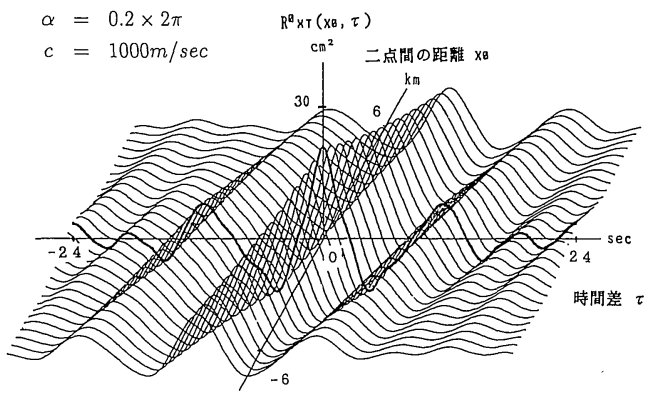

図一2 想定した相互相関関数 $R_{X T}^{0}\left(x_{0}, \tau\right) \quad($ 例一 -1$)$

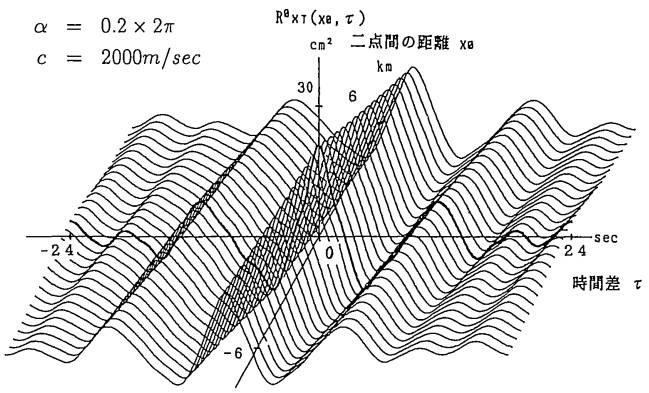

図一3 想定した相互相関関数 $R_{X T}^{0}\left(x_{0}, \tau\right) \quad($ 例一 2$)$

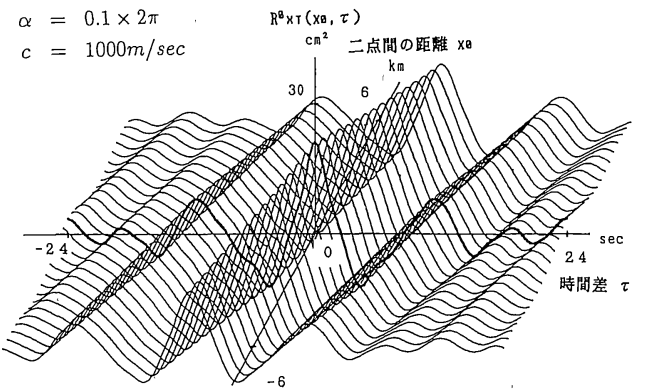

図一4 想定した相互相関関数 $R_{X T}^{0}\left(x_{0}, \tau\right) \quad($ 例一 3$)$

地点での波動のパワースペクトルから想定する.

(4) みかけの伝播速度 $c$, 変形定数 $\alpha$ を想定し, 式 (30) により,クロススペクトルを求める.

［方法 1］の場合

(5) 式（18）により，複素係数を求める.

(6) 式（19）により，付加雑音のクロススペクトルマ トリックスを求め, 式 (20) により, 互いに相関を 有する雑音波形をシミュレートする.

(7) 式（17）により，時空間地震波形をシミュレート する.

[方法 2] の場合

(5) 式 (24) （27）を用いて, 多地点の観測記録から, 


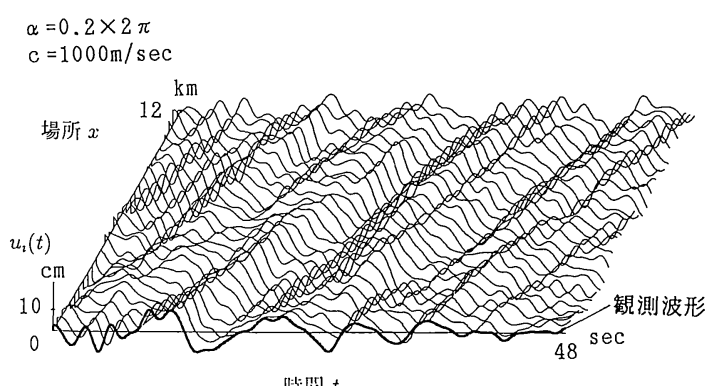

腾阳 $t$

図一5 時空間地震波形のサンプル $u_{i}(t)$ (観測地点数 $=1$, 例 -1 )

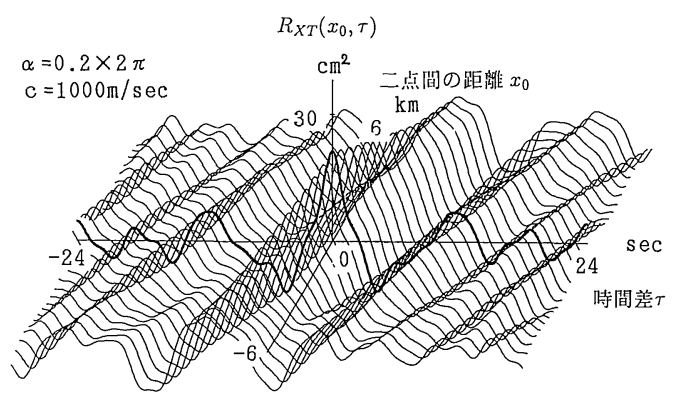

図一6 波形サンプル (図一5) の相互相関関数 $R_{X T}\left(x_{0}, \tau\right)$ （観測地点数 $=1$, 例一 1$)$

ある一地点の地震波形をシミュレートする.

(6) シミュレートした波形を観測記録に加えていくこ とで, 非観測地点の地震波形を順次シミュレートす る.

\section{6. 数值計算結果}

観測波形としては, Imperial Valley 地震 (1940 年 5 月 18 日, マグニチュード7.1) の El Centroの地点で 観測された南北方向の波形を使用した ${ }^{331}$. 本方向の加速 度記録は， $341.7 \mathrm{~cm} / \mathrm{s}^{2}$ の最大值を示したものであり， El Centro 地震波として, 建築物等の動的解析に用いら れる代表的な地震波形の一つである.この加速度記録を 積分した変位記録も発表されており ${ }^{331}$, 本解析では, 図 -1 に示す変位記録（最大值 $=10.9 \mathrm{~cm}$ ）を観測波形と して使用した.そして，観測波形の記録長 $T$ を $48 \mathrm{sec}$ として，フーリエ級数に展開した.

波形をシミュレートする地点 (場所) は, 地点間の距 離が $400 \mathrm{~m}$ で, 直線上に並んだ $0 \mathrm{~km}$ 地点から $12 \mathrm{~km}$ 地 点までの合計 31 地点とした.

\section{（1）想定した相互相関関数}

想定する相互相関関数は, 式 (31) で求める事ができ, 図一2, 図一3, 図一 4 に示す。図一2 は波動の伝播速度 を $c=1,000 \mathrm{~m} / \mathrm{sec}$, 変形定数を $\alpha=0.2 \times 2 \pi$ とした場合 (例一 1 ), 図一3 は波動の伝播速度を $c=2,000 \mathrm{~m} / \mathrm{sec}$, 変形定数を $\alpha=0.2 \times 2 \pi$ とした場合（例一 2 ), 図-4 は $\alpha=0.2 \times 2 \pi$

$\mathrm{c}=2000 \mathrm{~m} / \mathrm{s} \mathrm{ec}$

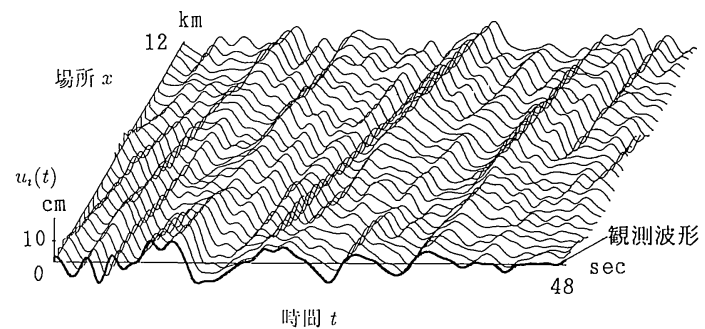

図一7 時空間地震波形のサンプル $u_{i}(t)$ （観測地点数 $=1$, 例一 2 ）

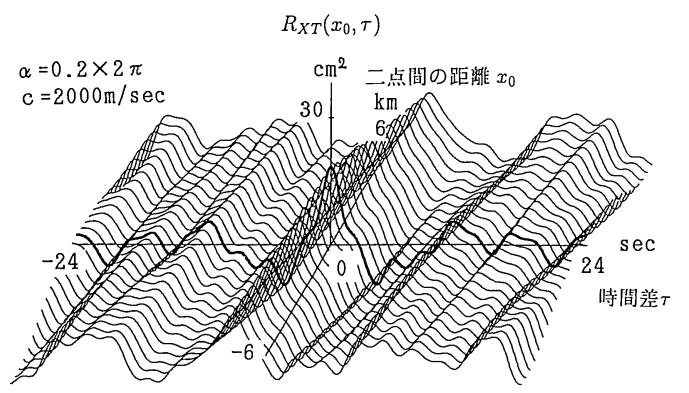

図一8 波形サンプル（図一7）の相互相関関数 $R_{X T}\left(x_{0}, \tau\right)$ （観測地点数 $=1$, 例一 2 )

$a=0.1 \times 2 \pi$

$c=1000 \mathrm{~m} / \mathrm{sec}$

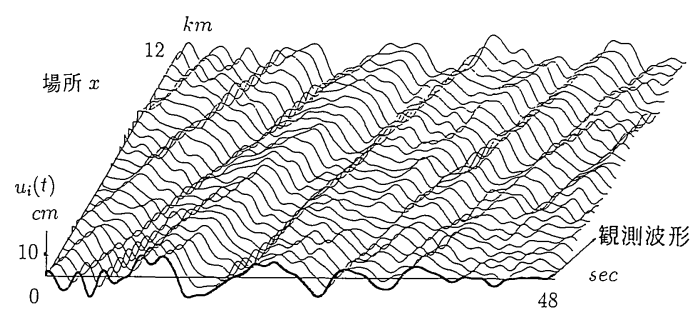

時間 $t$

図一9 時空間地震波形のサンプル $u_{i}(t)$ （観測地点数 $=1$, 例- 3 )

$$
\begin{aligned}
\alpha & =0.1 \times 2 \pi & R_{X T}\left(x_{0}, \tau\right) \\
c & =1000 \mathrm{~m} / \mathrm{sec} & \mathrm{cm}^{2} \text { 二点間の距離 } x_{0}
\end{aligned}
$$

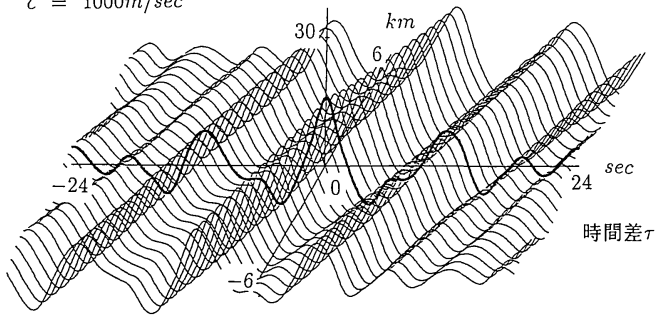

図一10 波形サンプル（図一9）の相互相関関数 $R_{X T}\left(x_{0}, \tau\right)$ (観測地点数 $=1$, 例 -3 )

波動の伝播速度を $c=1,000 \mathrm{~m} / \mathrm{sec}$, 変形定数を $\alpha=0.1$ $\times 2 \pi$ とした場合（例一 $3 ）$ である.ただし，ここでは， 
$\alpha=0.2 \times 2 \pi$

$\mathrm{c}=1000 \mathrm{~m} / \mathrm{sec}$

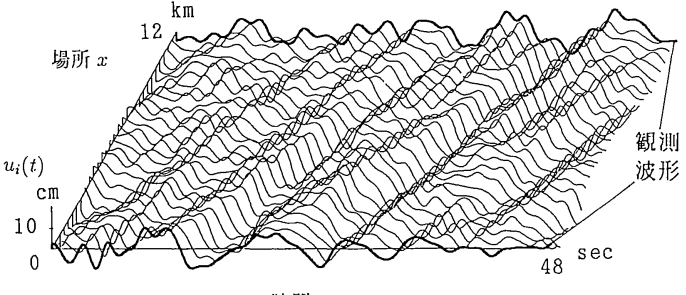

拈顾 $t$

図一11 時空間地震波形のサンプル $u_{i}(t)$ (観測地点数 $=2$, 例 -1 )

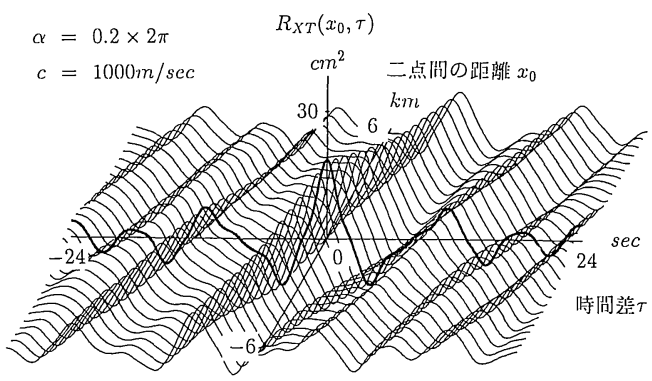

図一12 波形サンプル (図一11) の相互相関関数 $R_{X T}\left(x_{0}, \tau\right)$ (観測地点数 $=2$, 例 -1 )

場所に関しても定常であり，各地点の波動のパワースペ クトルは同一なものとしている. 従って, 図中の太線 $R_{X T}^{0}(0, \tau)$ は，図一-1 の観測波形の自己相関関数である.

\section{（2）観測地点が1地点の場合}

まず，観測記録が 1 地点で得られている場合を想定し た.ここでは, $0 \mathrm{~km}$ 地点を観測地点としている.

5. の手順に従い, 例-1〜 3 につい時空間地震波形 をシミュレートすることができた（図一5，図一7，図一 9). 図中の太線で示すように, 時空間波形は, 観測地点 において, 観測波形（図一1）と一致しており1.の条件

（B）を満足していることが確認できる.

伝播速度が同じで変形定数が違う場合の波形サンプル （図一 5 と図一9）を比較すると，波動の伝播に伴う波 形の変形の程度が異なっている様子がわかる，また，変 形定数が同じで伝播速度が違う場合の波形サンプル（図 -5 と図一7）を比較すると, 波形のピークの伝播の速 度が異なっている様子がわかる。

時空間の波形は, 確率量であり, 観測波形だけからは 一意に決まらないばかりでない, 前述のように, 伝播速 度, コヒーレンシーなどと関係する相互相関関数をよ゙う 想定するかによっても大きく異なることがわかる．相互 相関関数を精度良く推定することが, 現実により近い時 空間関数を得るのに重要なことである. また，アレ一観 測結果を用いてシミュレーション結果を検証することも 考えられる. $\alpha=0.2 \times 2 \pi$
$c=2000 \mathrm{~m} / \mathrm{sec}$

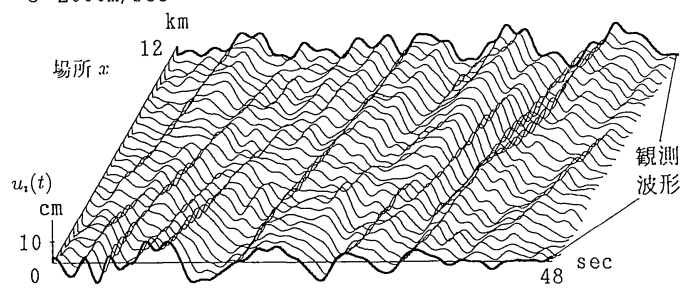

時間 $t$

図一13 時空間地震波形のサンプル $u_{i}(t)$ (観測地点数 $=2$, 例 -2 )

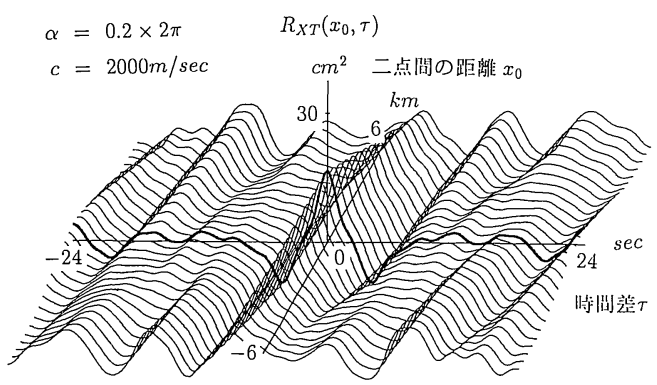

図一14 波形サンプル (図一13) の相互相関関数 $R_{X T}\left(x_{0}, \tau\right)$ (観測地点数 $=2$, 例 -2 )

$$
\alpha=0.1 \times 2 \pi
$$

$c=1000 \mathrm{~m} / \mathrm{sec}$

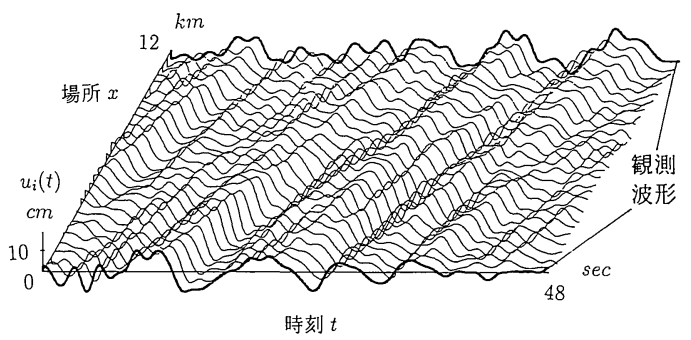

図一15 時空間地震波形のサンプル $u_{i}(t)$ （観測地点数 $=2$, 例 -3 )

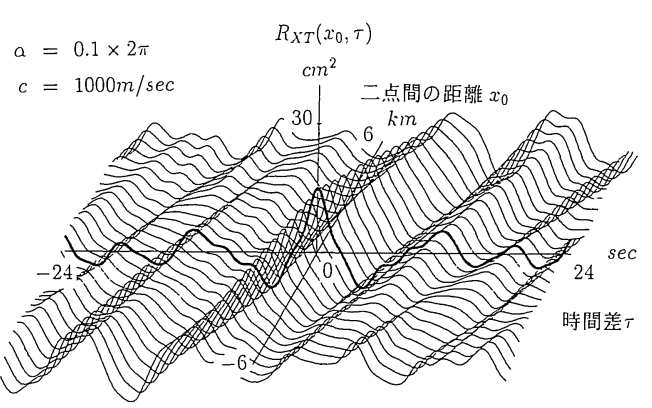

図一16 波形サンプル (図一15) の相互相関関数 $R_{X T}\left(x_{0}, \tau\right)$ (観測地点数 $=2$, 例-3)

シミュレートした波形サンプルから，相互相関関数を 時間差 $-24 \mathrm{sec} \leqq \tau \leqq+24 \mathrm{sec}$ ，二地点間距離 $-6 \mathrm{~km} \leqq x_{0}$ 


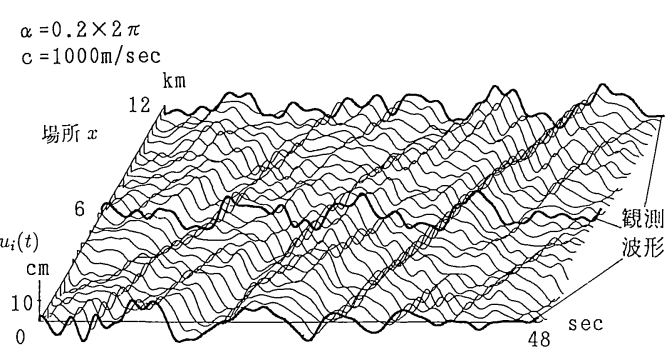

断阿 $t$

図一17 時空間地震波形のサンプル $u_{i}(t)$ (観測地点数 $=3$, 例- 1 )

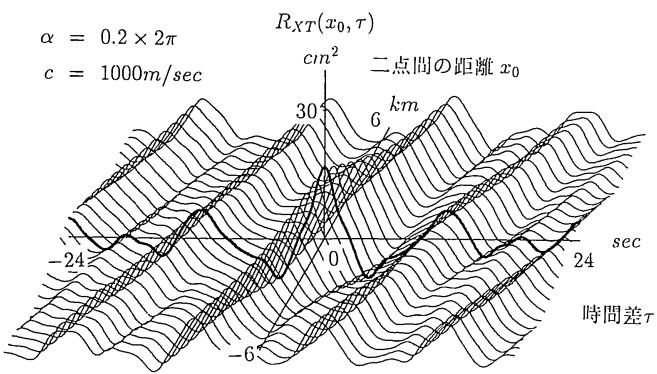

図一18 波形サンプル (図一17) の相互相関関数 $R_{X T}\left(x_{0}, \tau\right)$ (観測地点数 $=3$, 例一 1 )

$\leqq+6 \mathrm{~km}$ の範囲で計算した結果を図一6，図一8，図一 10 に示す.いずれの相互相関関数も想定した相互相関 関数（図一2〜図一4）に近似的なものになっている.

\section{（3）観測地点が2地点の場合}

観測記録が 2 地点で得られている場合を想定した。こ こでは, $0 \mathrm{~km}$ の地点と $12 \mathrm{~km}$ の地点とを観測地点とし ている. そして，12 km の地点の観測記録は，別に想定 したものであり，例 1〜3では同じものを使用している.

5. の手順に従い, 例-1〜 3 につて時空間地震波形 をシミュレートすることができた（図一11，図一13，図 一15). また，シミュレートした波形サンプルから求め た相互相関関数を図一12, 図一14, 図一16に示す. 波 形サンプル，相互相関関数に関して（2）と同様な考察 ができる.

\section{（4）観測地点が3地点の場合}

観測記録が 3 地点で得られている場合を想定した。こ こでは, $0 \mathrm{~km}$ 地点と $6 \mathrm{~km}$ 地点と $12 \mathrm{~km}$ 地点とを観測 地点としている.

図一17，19，21 に示すように，例-1〜 3 について時 空間地震波形をシミュレートすることができた。 また， シミュレートした波形サンプルから求めた相互相関関数 を図一18，図一20，図一22に示す．波形サンプル，相 互相関関数に関して（2）上同様な考察ができる.

シミュレートされた波形サンプルの相互相関関数は何 れも想定した相互相関関数（図一2～図一4）に近似的な $\alpha=0.2 \times 2 \pi$

$\mathrm{c}=2000 \mathrm{~m} / \mathrm{sec}$

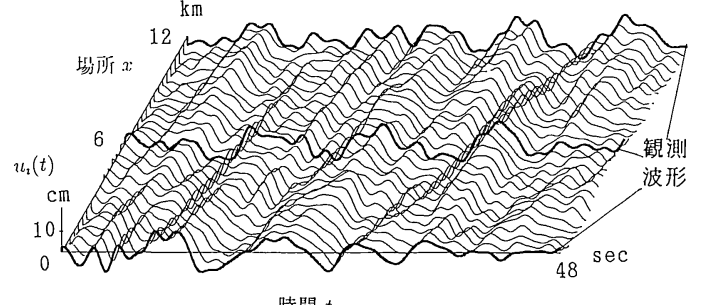

時間 $t$

図一19 時空間地震波形のサンプル $u_{i}(t)$ (観測地点数 $=3$, 例- 2 )

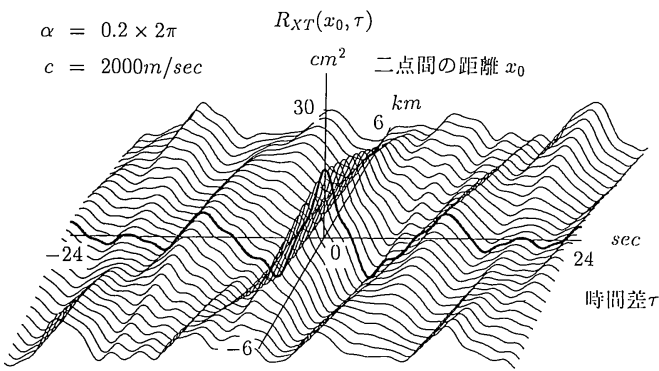

図一20 波形サンプル（図-19）の相互相関関数 $R_{X T}\left(x_{0}, \tau\right)$ (観測地点数 $=3$, 例一 2 )

$a=0.1 \times 2 \pi$

$c=1000 \mathrm{~m} / \mathrm{sec}$

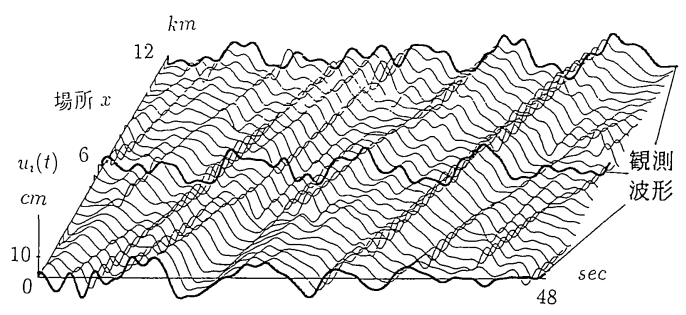

時間 $t$

図一21 時空間地震波形のサンプル $u_{i}(t)$ (観測地点数 $=3$, 例一 -3$)$

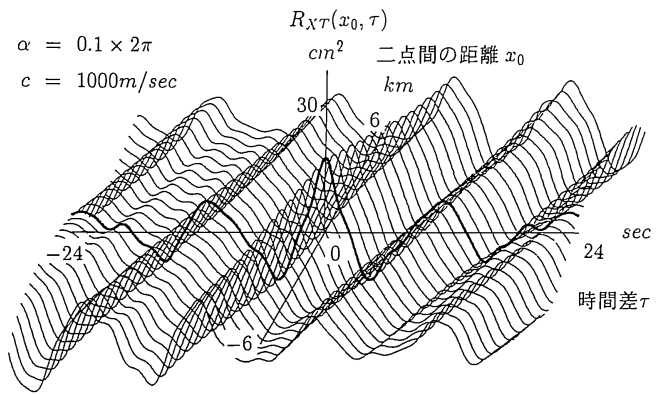

図一22 波形サンプル (図一21) の相互相関関数 $R_{X T}\left(x_{0}, \tau\right)$ (観測地点数 $=3$, 例- 3 )

ものになっている.しかし，得られた相互相関関数はサ ンプルによってかなりばらつくため, 設計に用いる時空 
間波形の作成に当たっては, 幾つかのサンプルのシミュ レーションを行い，相互相関関数の近似度の良いものを 使用する必要があると考える，このことは，参考文献 17)，20）で示した方法でも同様である.サンプルの相 互相関関数が想定したものに丁度一致するためには，参 考文献 18），19）で示した方法を使用する必要があると 考える.

また，本研究での相互相関関数の想定に際しては，少 数の限られた従来の研究結果に基づいた，地震波のみか けの伝播速度，コヒーレンシーを使用している．時空間 地震波形をより合理的にし，設計に利用できるようにす るためには，いろいろな地盤におけるアレー観測および 解析結果を集積することにより，これらのパラメータを より現実的な值にする必要があるものと考える.

\section{7. 結 論}

地震波動の伝播に伴う埋設管路の挙動を検討する際, 地震入力の時刻歴を管路に沿った各点でどのように与え るかが重要な問題である，本研究の目的は，観測された 多地点での強震記録を正確に満足する，時間と場所との 連続的な時空間関数としての地盤変位を合理的にシミュ レートする方法を展開する事である。

地盤の変位を, 埋設管路に沿った場所と時間とに関す る時空間確率過程とし，次の 2 つの条件を満足するもの と仮定する.

条件 (A)：時空間確率過程と観測波形との時間に関 する自己相関関数（またはパワースペクトル）は一致す る. 観測波形の自己相関関数之, 従来の研究に基づく, 地震波のみかけの伝播速度, 波形の変形の程度 (コヒー レンシー）とから，相互相関関数（またはクロススペク トル）を想定する．時空間確率過程の相互相関関数は, 想定した相互相関関数に一致する.

条件 (B) : 時空間確率過程は, 多地点の観測地点に おいては観測波形に厳密に一致する.

本論文で展開した手法は，従来の線形システム理論に 基づくものであり，非観測地点での地震波形を観測記録 を入力とする線形システムの出力として取り扱うもので ある. そして, Imperial Valley 地震での観測記録を用 いて, 波が正方向に伝播し，また，二地点間距離が離れ る程, 相関が減少するような相互相関関数を想定し, 時 空間関数としての波形をシミュレートした. そして, 得 られた時空間波形が，複数の観測地点においては観測波 形を満足している事を示した.

また，時空間波形の一つのサンプルから得られる自己 または相互相関関数が，想定した自己または相互相関関 数に近似的であることを示した.

謝辞：本研究をまとめるにあたり埼玉大学工学部渡辺啓
行先生に貴重な御助言を頂きました。記して感謝の意を 表します。

\section{参 考 文 献}

1）久保慶三郎：地震と土木構造物, 鹿島出版会, p. 127, 1981.

2）石油パイプライン事業の事業用施設の技術上の基準の細

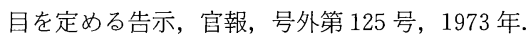

3) Tsuchida, H. and Kurata, E. : Observation of earthquake response of ground with horizontal and vertical seismometer arrays, 第 4 回日本地震工学シンポジウム, pp. 137 $\sim 144,1975$.

4) Tsuchida, H. and Iai, S. : Observation of earthquake response of ground with horizontal and vertical seismometer arrays ( 2 nd report), 第 5 回日本地震工学シンポ ジウム, pp. 169 176, 1980.

5）田村重四郎・加藤勝行・前田弘：軟弱地盤表面の線上に おける地震動の特性について, 土木学会第 29 回年次学術 講演会, pp. 538 539, 1974.

6）桜井彰雄 : 地盤の震動解析に基づく埋設パイプラインの 耐震性の研究, 1971 年 10 月.

7）川上英二・佐藤靖彦：地盤の相対変位・ひずみの推定結 果に及ぼす地震波形の変形の影響, 土木学会論文報告集, No. 337, pp. 37 46, 1983.

8) Shinozuka, M. and Lenoe, E. : A probabilistic model for spatial distribution of material properties. Engineering Fracture Mechanics, Vol.8, pp.217 227, 1976.

9) Shinozuka, M., Kameda, H. and Koike, T. : Ground strain estimation for seismic risk analysis, Journal of Engineering Mechanics, ASCE, Vol.109, No.1, pp.175 191, 1983.

10) Naganuma, T., Deodatis, G. and Shinozuka, M. : ARMA model for two-dimensional processes, Journal of Engineering Mechanics, ASCE, Vol.113, No.2, pp.234 251, 1987.

11）星谷勝・石井清・栗田博昭：空間時間分布特性を有する 地震動シミュレーション, 土木学会論文集, No. 386/I-8, pp. 359 367, 1987.

12) Hoshiya, M. and Chiba, T. : Simulation methods of multi-dimensional nonstationary stochastic processes by time domain models, 土木学会論文集，No.296，pp. 121 $\sim 130,1980$

13）原田隆典 - 篠塚正宣 : 表層地盤の確率応答と地震動の空 間一時間パワースペクトル, 第 19 回地震工学研 究発表 会講演概要, pp. 33 36, 1987.

14）否笠友紀・原田隆典：確率特性を有する地盤の応答と地 震動の空間一時間特性について, 土木学会第 43 回年次学 術講演会, I-463, pp. 976 977, 1988.

15) Harada, T. and Shinozuka, M. : Stochastic analysis of seismic ground motions in space and time, Proc., 9 WCEE, pp. II-825 830, 1988.

16) Deodatis, G. and Shinozuka, M. : Digital simulation of seismic ground motion using stochastic wave theory, Proc., 9 WCEE, pp. II-801 806, 1988.

17）川上英二・小野牧夫：一地点での観測記録を用いた時空 間地震波形のシミュレーション, 土木学会論文集, No. 441, pp. 167 175, 1992.

18）川上英二：一地点の観測記録を含む地震波形の時空間関 
数のシミュレーション，土木学会論文集, No. $410 / \mathrm{I}-12$, pp. 435 443, 1989.

19）门上英二：Imperial Valley 地震の観測記録を含む時空間 関数としての地震波形のシミュレーション, 第 8 回日本 地震工学シンポジウム, pp. 1311〜1316, 1990.

20）川上英二・小野牧夫：多変数 AR モデルを用いた観測記 録を含む時空間地震波形のシミュレーション, 埼玉大学 工学部建設系研究報告, Vol.22, 1992.

21）小野牧夫・川上英二：多地点での観測記録を用いた時空 間地震波形のシミュレーション, 土木学会第 47 回年次学 術講演会, I-636, pp. 1446〜1447, 1992.

22）盛川仁・亀田弘行：既知波形を条件とした確率波のシ ミュレーション, 土木学会第 46 回年次学術講演会, I-356, pp. $750 \sim 751,1991$.

23）盛川仁・亀田弘行：既知波形を含む条件付確率場のシ ミュレーション理諭, 都市耐震センター研究報告, 京都 大学防災研究所, 1991.

24) Vanmarcke, E.H. and Fenton, G.A. : Conditioned simulation of local fields of earthquake ground motion, Structural Safety, Vol.10, 1991.

25）星谷勝：確率場の条件付きシミュレーションに関する考 察, 土木学会第 47 回年次学術講演会, I-341, pp. 858 859, 1992.

26）丸山収・星谷勝：定常均一場の条件付き地震波動シミュ レーション, 土木学会第 47 回年次学術講演会, I-342, pp. 860 861, 1992.
27）土岐憲三・佐藤忠信 - 清野純史 ·水谷治弘:非均質な確率 場を考慮した時空間波形のシミュレーション, 土木学会 第 47 回年次学術講演会, I-340, pp. 856 857, 1992.

28) Shinozuka, M, and Jan, C.-M. : Digital simulation of random processes and its applications, Journal of Sound and Vibration, Vol.25, No.1, pp.111 128, 1972.

29）星谷勝：多次元確率過程のシミュレーション理論の物理 的意味について, 土木学会論文報告集, No.270, pp. 131 $\sim 134,1978$.

30）石井清：確率論手法による地震波の入力損失の効果の検 討, 第 16 回地震工学研究発表会講演概要, pp. 317 320, 1981.

31）沢田 勉：地震動の工学的諸特性の解析とその応用に関 する研究, 1988 年 8 月.

32) Katayama, T., Yamazaki, F., Nagata, S., Lu, L. and Turker, T. : Development of strong motion database for the Chiba seismometer array, Earthquake Disaster Mitigation Engineering, Institute of Industrial Science, University of Tokyo, January, 1990.

33) Hudson, D. et al. : Strong motion earthquake accelerograms, digitized and plotted data, EERL 71-50, California Institute of Technology, 1971.

34）川上英二・小野牧夫：多変数 AR モデルを用いた観測記 録を含む時空間地震波形, 土木学会論文集, No. 489, 1994.

(1993.3.19 受付)

\section{CONDITIONAL SIMULATION OF SPACE-TIME VARIATION OF EARTHQUAKE GROUND MOTION BY USING MULTI-INPUT LINEAR SYSTEMS THEORY

Records of strong motion are often used as the ground motion inputs in earthquake analysis and in the design of structures. The design of underground structures, however, requires more than just the time history at any particular point on the earth's surface. It also requires the space-time variation of the ground motion. We have therefore developed a method for generating a simulated space-time variation that includes strong ground motions recorded at observation points. This simulated variation is characterized by an apparent velocity and by a coherence function. Here we presented a case study using motion recorded during the 1940 Imperial Valley earthquake. 